\title{
Alterations in Thyroid Hormone Economy in Patients with Hydatidiform Mole
}

\author{
Valerie Anne Galton, Sidney H. Ingbar, Jesus Jimenez-F onseca, and \\ Jerome M. HerShMaN
}

From the Department of Physiology, Dartmouth Medical School, Hanover, New Hampshire; the Thorndike Memorial Laboratory and the Harvard Medical Services, Boston City Hospital, the Department of Medicine, Harvard Medical School, Boston, Massachusetts 02118; the Hospital de Gineco-Obstetricia numero dos, Centro Medico Nacional, Mexico 7, D. F., Mexico; and the Department of Medicine, University of Alabama School of Medicine, Birmingham, Alabama 35233

\begin{abstract}
A B S T R A C T Studies of several aspects of thyroid hormone economy have been conducted in 11 patients before and after removal of a molar pregnancy. Before evacuation of the mole, all patients demonstrated moderately to greatly elevated values for thyroidal ${ }^{131} \mathrm{I}$ uptake, absolute iodine uptake, and serum protein-bound- ${ }^{131} \mathrm{I}$. Values for serum PBI and serum thyroxine $\left(T_{4}\right)$ concentration were consistently and often greatly increased, averaging more than twice those found in normal pregnancy and three times those in normal controls. On the other hand, the maximum binding capacity of the $\mathrm{T}_{4-}$ binding globulin (TBG) was variably affected, and ranged between the values found in normal controls and those found in normal pregnancy. Values for the absolute concentration of free $T_{4}$ in serum were, on the average, only moderately elevated, since the proportion of free $T_{4}$ was moderately low, although not as low as in normal pregnancy. Sera of patients with molar pregnancy contained high levels of thyroid stimulating activity, as assessed in the McKenzie mouse bioassay system. The stimulator displayed a more prolonged duration of action than that of $\mathrm{TSH}$ and did not reveal a major immunological cross-reactivity with either human or bovine TSH, differing in the latter respect from the chorionic thyrotropin of normal human placenta. Abnormalities in iodine metabolism were rapidly ameliorated after removal of the molar pregnancy, and this was
\end{abstract}

This work was presented in part at the Annual Meeting of the American Thyroid Association, Washington, D. C., 1968.

Dr. Galton is a recipient of a U. S. Public Health Service Research Career Development Award 1-K3-AM-25, 375.

Received for publication 23 November 1970 and in revised form 11 February 1971. associated with the disappearance from serum of the thyroid stimulator.

Despite the foregoing evidence of thyroid hyperfunction and hypersecretion of $T_{4}$, patients with molar pregnancy were neither goitrous nor overtly thyrotoxic. They did display, however, high values of the urinary pigment/creatinine ratio, a possible indication of the presence of a hypermetabolic state.

It is concluded that in patients with molar pregnancy, thyroid function and $\mathrm{T}_{4}$ secretion are stimulated, often greatly so, by an unusual thyroid stimulator which is demonstrable in the blood and which is probably of molar origin. The nature of the stimulator, as well as the reasons for both the variability of the increase in TBG which occurs in molar pregnancy and the lack of frank thyrotoxicosis, remain to be clarified.

\section{INTRODUCTION}

Hydatidiform mole is the most frequent tumor of trophoblastic tissue; its frequency, geographical distribution, and pathogenesis have recently been reviewed (1). Dowling, Ingbar, and Freinkel first called attention to the occurrency of striking abnormalities in several aspects of thyroid hormone economy in patients with molar pregnancy (2). They found marked increases in serum PBI, $\mathrm{PB}^{131} \mathrm{I}$, butanol-extractable ${ }^{181} \mathrm{I}$, thyroidal ${ }^{131} \mathrm{I}$ uptake, and absolute iodine uptake (AIU) ${ }^{1}$ in one or more of

${ }^{1}$ Abbreviations used in this paper: AIU, absolute iodine uptake; HCG, human chorionic gonadotrophin; $\mathrm{P} / \mathrm{C}$, urinary pigment/creatinine ratio; $T_{3}$, triiodothyronine; $T_{4}$, thyroxine; TBG, $\mathrm{T}_{4}$-binding globulin; TBPA, thyroxine-binding prealbumin; TCA, trichloroacetic acid. 
three patients studied. More recently, Kock, Kessel, Stolte, and Leusden confirmed the elevation of PBI in six patients, and found that the resin uptake of ${ }^{131} \mathrm{I}-\mathrm{la}$ beled triiodothyronine $\left(T_{3}\right)$, assessed in two patients, was in the same range as in normal pregnancy. An ${ }^{131} \mathrm{I}-$ tracer test performed in one patient indicated a very high thyroidal ${ }^{131} \mathrm{I}$ uptake, conversion ratio, and thyroidal ${ }^{131}$ I-secretion rate $(3)$.

In all of the foregoing studies, the patients with molar pregnancy were apparently not thyrotoxic. Therefore it seemed important to ascertain whether the iodinated materials being synthesized in the thyroids of seemingly euthyroid patients with molar pregnancy were in fact thyroxine $\left(T_{4}\right)$, whether the increase in serum PBI represented an increase in $T_{4}$ or other iodinated materials, and to what extent, if any, the increase could be attributed to an increase in the activity of serum thyroxine-binding globulin ( $\mathrm{TBG}$ ), analogous to that which occurs in normal pregnancy $(4,5)$. The present report describes the findings obtained in 11 patients in whom several aspects of thyroid hormone economy were studied before and after termination of a molar pregnancy. As a possible index of metabolic state, measurements were also made of the urinary pigment/creatinine ratio (6-8). Studies of thyroid hormone concentration and binding in the serum of nine other patients are also presented.

\section{METHODS}

Patient material and general procedures. All patients were studied at the Hospital de Gineco Obstetricia, numero dos, Centro Medico Nacional, Mexico City. Control ob-

TABLE I

Clinical Data of Patients with Molar Pregnancy\$

\begin{tabular}{ccrrrrr}
\hline & \multicolumn{5}{c}{$\begin{array}{c}\text { Obstetric } \\
\text { history }\end{array}$} & \multicolumn{1}{c}{ Date of } \\
Patient & Age & G & P & \multicolumn{1}{c}{$\begin{array}{c}\text { Date of } \\
\text { evacuation }\end{array}$} & $\begin{array}{c}\text { Urinary } \\
\text { HCG* }\end{array}$ \\
\cline { 3 - 4 } & & & & & & \multicolumn{1}{c}{ IU/24 hr } \\
4 & 23 & 4 & 2 & $5-10-67$ & $10-03-67$ & $1,024,000$ \\
8 & 22 & 4 & 3 & $6-10-67$ & $9-28-67$ & $1,024,000$ \\
10 & 24 & 4 & 3 & $4-15-67$ & $10-06-67$ & $1,024,000$ \\
12 & 33 & 4 & 3 & $7-17-67$ & $10-24-67$ & 512,000 \\
14 & 30 & 12 & 8 & $6-17-67$ & $11-10-67$ & 512,000 \\
17 & 32 & 7 & 6 & $9-09-67$ & $12-27-67$ & 512,000 \\
25 & 17 & 1 & 0 & $12-28-67$ & $3-27-68$ & 512,000 \\
27 & 26 & 5 & 4 & $1-12-69$ & $4-10-68$ & $1,024,000$ \\
29 & 23 & 2 & 0 & $12-17-68$ & $5-11-68$ & $1,024,000$ \\
$32 \ddagger$ & 35 & 11 & 9 & $3-09-68$ & $5-28-68$ & $1,024,000$ \\
34 & 22 & 2 & 1 & $12-27-68$ & $6-11-68$ & $1,024,000$ \\
\hline
\end{tabular}

* Urinary HCG levels in normal pregnancy averaged 20,000 IU $/ 24 \mathrm{hr}$.

$\ddagger$ Patient evacuated of both a fetus and molar tissue.

$\S \mathrm{G}$, gravidity; $\mathrm{P}$, parity; LMP, last menstrual period. servations were made in members of the staff of this institution. Pertinent clinical data concerning the patients with molar pregnancy are presented in Table I. The diagnosis of molar pregnancy was based on clinical findings and on the demonstration of a high titer of human chorionic gonadotrophin (HCG) in the urine. In all patients studied, the diagnosis was ultimately confirmed at curettage. Generally, delivery was induced by means of oxytocin about $48 \mathrm{hr}$ after the diagnosis was made, and completeness of delivery was ascertained by subsequent dilatation and curettage. During the 48-hr period before induction, the following routine was adopted. Each patient underwent physical examination for signs of thyroid abnormality. At 0 and 24 $\mathrm{hr}$, blood was drawn, and the serum obtained was frozen for later use in the several analyses to be performed. A portion of urine was obtained and was analyzed immediately for both urinary pigment (urochrome) and creatinine. A tracer dose of ${ }^{131} \mathrm{I}$ was administered and its uptake in the thyroid measured $24 \mathrm{hr}$ later. A concomitant urine collection was made for measurement of the 24-hr excretion of ${ }^{131} \mathrm{I}$. Portions of these urine collections were stored frozen for subsequent measurement of stable iodine concentration. A portion of serum obtained $24 \mathrm{hr}$ after ${ }^{131} \mathrm{I}$ administration was employed for determination of the serum $\mathrm{PB}^{181} \mathrm{I}$ concentration.

At 1 and 4 wk after delivery of the molar tissue, and in a few cases more frequently, additional blood and urine samples were obtained. The 24 -hr thyroidal uptake of ${ }^{181} \mathrm{I}$ was repeated in four patients at. $1 \mathrm{wk}$, and in six at $4 \mathrm{wk}$ postdelivery.

The nonpregnant control group consisted of nine Mexican females of an age range and socioeconomic status similar to that of the patients. All denied taking any medication. The pregnant controls consisted of hospital outpatients with uncomplicated pregnancy, patients undergoing normal labor, and the same patients at 3 and 6 days post partum.

Analytical techniques. The $\mathrm{PB}^{131} \mathrm{I}$ concentration in serum was determined by a standard trichloroacetic acid (TCA) precipitation technique. 2 volumes of $10 \%$ TCA were mixed with $3 \mathrm{ml}$ serum containing added stable iodide $(100 \mu \mathrm{g} / \mathrm{ml})$. The precipitate was centrifuged and washed three times with 2 volumes of $5 \%$ TCA. The washed precipitate was dissolved in $20 \% \mathrm{NaOH}$ for counting and its radioactivity was compared with that in a portion of the administered dose. Except where otherwise specified, the percentage of free $T_{4}$ in serum was determined by the equilibrium dialysis method of Ingbar, Braverman, Dawber, and Lee (9). Serum PBI was measured in duplicate in the authors' laboratories by an auto-analyzer technique. For samples in which values in excess of $20 \mu \mathrm{g}$ per $100 \mathrm{ml}$ were found, analyses were repeated using a 2 -fold dilution of serum. Serum $T_{4}$ concentration was measured by the radioligand-binding displacement method of Murphy and Pattee (10), and urinary iodine by the method of Benotti and Benotti (11).2 The maximum binding capacities of serum TBG and thyroxinebinding prealbumin (TBPA) were assessed by reverse flow filter paper electrophoresis employing glycine-acetate buffer, $\mathrm{pH} 8.6$ (12). Urinary pigment concentration was measured directly in centrifuged specimens at $420 \mathrm{~m} \mu$ in a Coleman Junior Spectrophotometer (Coleman Instruments, Maywood, III.), and urinary creatinine concentration was measured at $495 \mathrm{~m} \mu$ after addition of alkaline picrate reagent. Details of these methods and the calculation of the urinary pigment/

\footnotetext{
${ }^{2}$ Measurements were made in the Boston Medical Laboratory, Boston, Mass.
} 
TABLE II

Thyroid Function in Patients with Molar Pregnancy

\begin{tabular}{|c|c|c|c|c|c|c|c|c|c|c|c|}
\hline \multirow{3}{*}{ Patient } & \multicolumn{3}{|c|}{ 131I uptake } & \multicolumn{2}{|c|}{$24 \mathrm{hr}$ PB ${ }^{131} \mathrm{I}$} & \multicolumn{3}{|c|}{ Urinary/ iodide excretion } & \multicolumn{3}{|c|}{ Absolute iodine uptake } \\
\hline & \multirow[t]{2}{*}{ Predelivery } & \multicolumn{2}{|c|}{ Postdelivery } & \multirow[t]{2}{*}{ Predelivery } & \multirow{2}{*}{$\begin{array}{l}\text { Postde- } \\
\text { livery } \\
>4 \text { wk }\end{array}$} & \multirow[t]{2}{*}{ Predelivery } & \multicolumn{2}{|c|}{ Postdelivery } & \multirow[t]{2}{*}{ Predelivery } & \multicolumn{2}{|c|}{ Postdelivery } \\
\hline & & 1 wk & $>4 \mathrm{wk}$ & & & & $1 \mathrm{wk}$ & $>4 \mathrm{wk}$ & & $1 \mathrm{wk}$ & $>4 \mathrm{wk}$ \\
\hline & \multicolumn{3}{|c|}{$\%$ dose $/ 24 \mathrm{hr}$} & \multicolumn{2}{|c|}{$\%$ dose/liter serum } & \multicolumn{3}{|c|}{$\mu g / 24 h r$} & \multicolumn{3}{|c|}{$\mu g I / 24 h r$} \\
\hline 4 & 60 & - & 23 & 0.29 & - & 94 & & 91 & 191 & - & 36 \\
\hline 8 & 50 & - & - & - & - & 51 & & - & 571 & - & - \\
\hline 10 & 67 & - & - & 0.17 & - & 148 & & - & 1478 & - & 一 \\
\hline 12 & 83 & 一 & 34 & 0.23 & 0.067 & 40 & & 177 & 1386 & - & 135 \\
\hline 14 & 73 & - & - & 0.29 & - & 92 & & - & 247 & - & - \\
\hline 17 & 65 & - & 32 & 0.46 & 0.090 & - & & 一 & - & - & - \\
\hline 25 & - & 47 & 27 & - & - & - & 100 & 131 & - & 90 & 148 \\
\hline 27 & 74 & 53 & 36 & 0.82 & 0.03 & 253 & 74 & 182 & 2144 & 1027 & 33 \\
\hline 29 & 62 & 26 & 27 & 0.13 & - & 88 & 173 & 128 & 195 & 42 & 36 \\
\hline 32 & 41 & 29 & - & 0.48 & - & 5250 & 2215 & - & 15960 & 764 & - \\
\hline 34 & 56 & - & - & - & - & 288 & - & - & 328 & - & - \\
\hline Mean \pm SE & $63 \pm 3.9$ & & & $0.36 \pm 0.079$ & & $700 \pm 569$ & & & $2500 \pm 1698$ & & \\
\hline
\end{tabular}

creatinine ratio are presented elsewhere (13). The uptake of ${ }^{181} \mathrm{I}$ by the thyroid was determined in the radioisotope laboratory of the Hospital General, Centro Medico Nacional, through the courtesy of Dr. A. Cuaron.

Values for the 24-hr absolute thyroidal iodine uptake (AIU) were calculated as the product of the daily urinary iodine excretion and the quotient of the thyroidal ${ }^{181} \mathrm{I}$ uptake and the 24-hr urinary ${ }^{181} \mathrm{I}$ excretion.

Human pituitary TSH was measured in unextracted serum by a specific radioimmunoassay, modified from that of Odell, Rayford, and Ross (14). The serum samples were also assayed for a placental thyrotropin in a radioimmunoassay for beef $\mathrm{TSH}$ using a double antibody technique described previously (15). A thyrotropic substance extracted from normal human placentas cross-reacts in this beef immunoassay (16). Bioassay for thyroid stimulating activity in unextracted serum samples was performed by a modification of the McKenzie mouse bioassay method (16). Each mouse was injected intravenously with $0.5 \mathrm{ml}$ serum, 4-6 mice per sample. To ascertain whether the biological activity in serum could be neutralized by anti-TSH antibody, samples of serum were reacted for $18 \mathrm{hr}$ at $2^{\circ} \mathrm{C}$ with an antibody to human pituitary TSH. The amount of antibody employed was that which produced complete neutralization of a quantity of human TSH comparable in biological activity to that of the serum sample.

Statistical analyses were conducted employing Student's $t$ test, as described by Snedecor and Cochran (17).

\section{RESULTS}

Indices of thyroid function (Table II). For the laboratory in which the studies were done, the mean value for the 24-hr thyroidal uptake of ${ }^{181} \mathrm{I}$ in nonpregnant euthyroid women was $35 \pm 6.5 \%$ (mean $\pm \mathrm{SE}$ ), range 10 $50 \%$. In 10 patients with molar pregnancy studied before delivery, the $24-\mathrm{hr}$ uptake of ${ }^{131} \mathrm{I}$ averaged $63 \pm 4.0 \%$ (range $41-83 \%)$, a highly significant increase $(P<$ $0.001)$. Values of $50 \%$ or more were observed in 8 of the 10 patients. The lowest value $(41 \%)$ was seen in patient 32 who may have been exposed to excess iodide, since urinary iodine excretion was greatly increased. In the seven patients studied after evacuation of the mole, ${ }^{191}$ I uptake declined rapidly, reaching values within the normal range by the time of first postdelivery measurement (1-4 wk).

Values for the 24-hr urinary excretion of ${ }^{181} \mathrm{I}$ and ${ }^{127} \mathrm{I}$ were measured during the 24 -hr period in which thyroidal ${ }^{131} \mathrm{I}$ uptake was being determined so that absolute rates of thyroidal iodine uptake could be calculated. One patient (No. 32) was found to have a greatly elevated value for urinary iodine $(5250 \mu \mathrm{g} / 24 \mathrm{hr})$. That this was not due to external contamination is strongly indicated by the finding that the urinary iodine excretion $1 \mathrm{wk}$ after delivery of the mole was $2215 \mu \mathrm{g} / 25 \mathrm{hr}$. If values in this patient were excluded, mean iodine excretion in the remaining eight patients was $125 \mu \mathrm{g} / 24 \mathrm{hr}$, ranging between 40 and $288 \mu \mathrm{g} / 24 \mathrm{hr}$. Except in patient 32, cited above, no consistent or pronounced change in urinary iodine excretion occurred after delivery of the mole.

The calculated value of the AIU in patient No. 32 was exceedingly high $(15,960 \mu \mathrm{g} / 24 \mathrm{hr})$ as a result of persistence of a $41 \%$ thyroidal ${ }^{181} \mathrm{I}$ uptake in the face of an apparent great increase in urinary iodine excretion. Within 1 wk after delivery of the mole, AIU had decreased to $764 \mu \mathrm{g} / 24 \mathrm{hr}$. In the remaining eight patients, values for AIU averaged $817 \mu \mathrm{g} / 24 \mathrm{hr}$ and ranged between 191 and $2144 \mu$ g. $^{3}$ In the five patients in whom appropriate observations were possible, delivery of the mole was followed within $1-4$ wk by a striking reduction in thyroidal AIU.

${ }^{8}$ Values for the normal AIU in Mexico City have not been determined; however, in the continental United States, reported average normal values have ranged between approximately 70 and $120 \mu \mathrm{g} /$ day $(2,18,19)$. 
TABLE III

Concentration and Physical State of Thyroxine $\left(T_{4}\right)$ in Serum in Normal and Molar Pregnancy (First Series)

\begin{tabular}{|c|c|c|c|c|c|c|c|}
\hline \multirow[b]{2}{*}{ Group or patient } & \multirow[b]{2}{*}{ Serum PBI } & \multicolumn{2}{|c|}{ Serum $T_{4}$} & & & \multicolumn{2}{|c|}{ Maximum $T_{4}$-binding capacity } \\
\hline & & Measured & Calculated* & \multicolumn{2}{|c|}{ Serum free $T_{4}$} & TBG & TBPA \\
\hline & $\mu \mathrm{g} / 100 \mathrm{ml}$ & \multirow{2}{*}{\multicolumn{2}{|c|}{$\mu g / 100 \mathrm{ml}$}} & $\%$ total $T_{4}$ & $n g / 100 \mathrm{ml} \ddagger$ & \multicolumn{2}{|c|}{$\mu g T_{4} / 100 \mathrm{ml}$} \\
\hline \multicolumn{6}{|c|}{ Molar Pregnancy (11)§ } & & \\
\hline 4 & 14.5 & 17.5 & 22.3 & 0.020 & 4.5 & 35.2 & 213 \\
\hline 8 & 22.5 & - & 34.6 & 0.062 & 21.4 & 23.0 & 207 \\
\hline 10 & 20.8 & 20.0 & 32.0 & 0.032 & 10.2 & 32.0 & 244 \\
\hline 12 & 20.0 & 27.0 & 30.8 & 0.039 & 12.0 & 32.3 & 246 \\
\hline 14 & 12.7 & - & 19.4 & 0.036 & 7.0 & 23.0 & 200 \\
\hline 17 & 18.0 & - & 27.7 & 0.046 & 12.7 & 30.0 & 249 \\
\hline 25 & 22.0 & - & 33.8 & - & - & 17.5 & 250 \\
\hline 27 & 36.0 & 46.0 & 55.4 & 0.044 & 24.4 & 17.0 & 206 \\
\hline 29 & 23.0 & 34.0 & 35.4 & 0.018 & 6.4 & 27.0 & 198 \\
\hline 32 & 17.6 & - & 27.1 & 0.050 & 13.5 & 27.5 & 150 \\
\hline 34 & 22.0 & - & 33.8 & 0.044 & 14.9 & 42.5 & 200 \\
\hline Mean $\pm \mathrm{SE}$ & $20.8 \pm 1.8$ & $29.9 \pm 5.2$ & $32.0 \pm 2.8$ & $0.039 \pm 0.004 \uparrow$ & $12.7 \pm 2.0$ ฯ & $27.9 \pm 2.3$ & $215 \pm 9.2$ \\
\hline \multicolumn{8}{|c|}{ Postdelivery $1 \mathrm{wk}(7)$} \\
\hline Mean \pm SE & $8.5 \pm 1.0$ & & $13.1 \pm 1.5$ & & & & \\
\hline \multicolumn{8}{|c|}{ Postdelivery 4 wk (7) } \\
\hline Mean $\pm \mathrm{SE}$ & $6.2 \pm 0.711$ & & $9.5 \pm 1.1$ & $0.047 \pm 0.006$ & $4.1 \pm 0.7$ & $20.6 \pm 2.911$ & $278 \pm 7.911$ \\
\hline \multicolumn{8}{|c|}{ Normal pregnancy 1 st trimester } \\
\hline Mean $\pm \mathrm{SE}$ & $8.5 \pm 4 \|(6)$ & & $13.1 \pm C .6$ & $0.038 \pm 0.007$ & $5.2 \pm 1.2(4)$ & $31.4 \pm 2.4(5)$ & $232 \pm 12(5)$ \\
\hline \multicolumn{8}{|c|}{ Normal pregnancy 2 nd trimester } \\
\hline Mean $\pm \mathrm{SE}$ & $8.7 \pm 0.5^{\prime \prime}(16)$ & & $13.4 \pm 0.8$ & $0.036 \pm 0.003 \rrbracket$ & $4.7 \pm 0.6(7)$ & $36.7 \pm 2.7(16)$ & $260 \pm 13 \rrbracket(16)$ \\
\hline \multicolumn{8}{|c|}{ Normal pregnancy 3 rd trimester } \\
\hline Mean $\pm \mathrm{SE}$ & $9.1 \pm 0.3^{\prime \prime}(18)$ & & $14.0 \pm 0.5$ & $0.034 \pm 0.001 \Upsilon$ & $4.8 \pm 0.3(7)$ & $42.4 \pm 1.9 \|(18)$ & $253 \pm 16 \pi(11)$ \\
\hline \multicolumn{8}{|c|}{ Normal pregnancy Term } \\
\hline \multicolumn{8}{|c|}{ Postpartum 1 wk (5) } \\
\hline \multicolumn{8}{|c|}{ Nonpregnant controls } \\
\hline Mean $\pm \mathrm{SE}$ & $6.0 \pm 0.2(9)$ & & $9.2 \pm 0.3$ & $0.059 \pm 0.008$ & $5.5 \pm 0.5(7)$ & $18.8 \pm 0.7(9)$ & $242 \pm 12(9)$ \\
\hline
\end{tabular}

* Calculated as PBI/0.65.

$\ddagger$ Based on $\%$ total $T_{4}$ and calculated serum $T_{4}$ concentration.

$\S$ Numbers in parentheses indicate number of patients.

1" Significantly different from molar pregnancy preevacuation group, $P<0.05$.

T Significantly different from nonpregnant group, $P<0.05$.

Values of the $\mathrm{PB}^{131} \mathrm{I}$ at $24 \mathrm{hr}$ were above the upper limit of normal $(0.1 \%$ dose $/ 1)$ in all of the eight patients in whom this measurement was made before removal of the mole, averaging $0.37 \%$ dose $/ 1$ (range, $0.13-0.82$ ). In the three patients studied after removal of the mole, values for $\mathrm{PB}^{131} \mathrm{I}$ had undergone a striking decrease into the normal range by 4 wk postdelivery.

Thyroid hormone in the blood. Results of analyses for serum PBI are shown in Table III. The mean PBI in nonpregnant Mexican women was $6.0 \pm 0.2 \mu \mathrm{g} / 100 \mathrm{ml}$. The increase in serum PBI normally associated with uncomplicated pregnancy was evident in specimens obtained during all three trimesters $(4,5)$. This increase was maintained for at least the first 6 days postpartum. In patients with molar pregnancy, the mean serum $\mathrm{PBI}$ concentration was $20.8 \pm 1.8 \mu \mathrm{g} / 100 \mathrm{ml}, 2-3$ times that found in normal pregnancy. After delivery of the mole, the PBI dropped rapidly during the first wk, and was normal within a month. $T_{4}$ concentration was measured in serum obtained from five patients. As shown in Table III, the serum $T_{4}$ concentration in all was greater than that expected in normal pregnancy (10), averaging 29 $\mu \mathrm{g} / 100 \mathrm{ml}$ (range 17.5-46.0). Measured values for serum $\mathrm{T}_{4}$ agreed reasonably well with values calculated by dividing the PBI by 0.65 , the fractional mol wt of iodine in $T_{4}$. In this group of patients, serum $T_{4}$ concentrations 
measured directly averaged $82 \%$ of values calculated from the PBI.

Values for the maximum $\mathrm{T}_{4}$-binding capacity of serum TBG in nonpregnant Mexican women $(18.8 \pm 0.7 \mu \mathrm{g}$ $\mathrm{T}_{4} / 100 \mathrm{ml}$ ) were in the range reported by others for American women, and the usual marked increase in T4-binding capacity associated with normal pregnancy was observed (Table III) $(4,5)$. In patients with molar pregnancy, an increase in the $\mathrm{T}_{4}$-binding capacity of TBG was often, although not invariably, observed, but only occasionally to the level seen in normal pregnancy. Values ranged between $17-43 \mu \mathrm{g} \mathrm{T}_{4} / 100 \mathrm{ml}$ serum. In individual patients with molar pregnancy, no correlation was observed between the degree of increase in the PBI and the maximum $T_{4}$-binding capacity of TBG. Normal values were restored by $4 \mathrm{wk}$ after delivery of the mole. The $T_{4}$-binding capacity of TBPA in the serum of patients with normal pregnancy was not significantly different from that obtained by the same technique in normal nonpregnant controls $(242 \pm 12 \mu \mathrm{g} / 100 \mathrm{ml})$. Values in molar pregnancy $(215 \pm 9.2 \mu \mathrm{g} / 100 \mathrm{ml})$, however, were significantly lower than those found in normal pregnancy $(P<0.05)$. Within a month after evacuation of the mole, the $\mathrm{T}_{4}$-binding capacity of TBPA was somewhat higher than normal.

Radioautographs of paper electrophoretograms obtained during analyses for TBG and TBPA revealed no binding of $T_{4}$ in zones associated with other proteins, aside from albumin.

The percentage and absolute concentrations of free $T_{4}$ in the serum of patients with normal and molar pregnancy are also shown in Table III. In accord with earlier observations, the percentage of free $T_{4}$ in serum was significantly decreased during normal pregnancy $(9,20)$. The absolute concentration of free $T_{4}$ in serum, however, was only slightly, and not significantly, lower than normal. In molar pregnancy, the mean percentage of free $T_{4}(0.039 \pm 0.004)$ was reduced to about the same degree as in normal pregnancy. However, owing to the very marked increase in serum PBI, the absolute concentration of free $T_{4}$ in the serum of patients with molar pregnancy $(12.7 \pm 2.0 \mathrm{ng} / 100 \mathrm{ml})$ was significantly higher than normal $(5.5 \pm 0.5 \mathrm{ng} / 100 \mathrm{ml}, P<$ $0.05)$. In patients with molar pregnancy, values for the per cent and absolute concentration of free $T_{4}$ had returned toward or into the normal range by $4 \mathrm{wk}$ after delivery.

Concern was felt about the accuracy of some of these measurements, in particular the free $T_{4}$ analyses, since the equipment used in Mexico was not entirely adequate and strict regulation of the bath temperature during the equilibrium dialysis was difficult to attain. Furthermore, samples of serum were frozen for varying lengths of time before shipment to the United States for determi- nation of $\mathrm{PBI}$ and serum $\mathrm{T}_{4}$; in one instance considerable delay in delivery was encountered. Thus, it seemed possible that deterioration of the samples may have influenced the data. Therefore, samples of serum were obtained subsequently from nine additional cases of molar pregnancy admitted to the same hospital in Mexico (series 2). These were frozen until shipment within a month to the United States, where free $T_{4}$ analyses were performed under well standardized conditions. The concentrations of PBI and $T_{4}$ in serum and the maximum $\mathrm{T}_{4}$-binding capacity of TBG were also measured. For comparison, similar studies were performed on samples of serum from eight nonpregnant women and eight women with normal pregnancies. The results obtained are shown in Table IV. Values obtained for serum PBI and the $T_{4}$-binding capacity of TBG were very similar to those obtained in the original series of samples ( $\mathrm{Ta}$ ble III). In this group of specimens, however, a closer agreement was noted between measured values of the serum $\mathrm{T}_{4}$ concentration and those calculated from measurements of the serum PBI, the former averaging 95\% of the latter. Again, in patients with molar pregnancy, values for the serum PBI $(19.2 \pm 2.0 \mu \mathrm{g} / 100 \mathrm{ml})$ were approximately twice those found in patients with normal pregnancy $(7.9 \pm 0.4 \mu \mathrm{g} / 100 \mathrm{ml})$. In this group of specimens, the percentage of free $T_{4}$ was measured by the dilution method of Oppenheimer, Squef, Surks, and Haver (20), and values were generally lower than those obtained by the previous technique. Normal values for the percentage of free $T_{4}$ averaged $0.028 \pm 0.001$. A significant decrease was found in sera obtained from patients with normal pregnancy $(0.021 \pm 0.001)$. Values in patients with molar pregnancy varied widely, the mean $(0.024 \pm 0.0018)$ falling between that obtained in nonpregnant controls and that obtained in normal pregnancy. As a result of the very high values for serum PBI (and serum $T_{4}$ ), calculated values for the absolute concentration of free $T_{4}$ averaged more than 3 times the average of values found in normal controls and more than twice the average of those found in normal pregnancy.

Urinary pigment/creatinine ratio. Values of the urinary pigment/creatinine $(\mathrm{P} / \mathrm{C})$ ratio were approximately twice normal in patients with uncomplicated pregnancy. In molar pregnancy, the ratio was, in turn, increased to values more than twice those found in normal pregnancy (Table $\mathrm{V}$ ). The ratio fell rapidly during the 1st wk after evacuation of the mole, and by $4 \mathrm{wk}$ was not significantly different from normal.

Thyroid stimulator in serum. Bioassay according to a modified McKenzie technique revealed the presence of high concentrations of a thyroid stimulator in the sera of all patients examined before evacuation of the mole (Table VI). There was no detectable thyrotropic 
TABLE IV

Concentration and Physical State of Thyroxine $\left(T_{4}\right)$ in Serum in Normal and Molar Pregnancy (Second Series)

\begin{tabular}{|c|c|c|c|c|c|c|}
\hline \multirow[b]{2}{*}{ Group or patient } & \multirow[b]{2}{*}{ Serum PBI } & \multicolumn{2}{|c|}{ Serum $T_{4}$} & \multirow{2}{*}{\multicolumn{2}{|c|}{ Serum free $T_{4}$}} & \multirow{3}{*}{$\begin{array}{c}\begin{array}{c}\text { Maximum } T_{4-} \\
\text { binding capacity } \\
\text { of TBG }\end{array} \\
\mu g T_{4} / 100 \mathrm{ml}\end{array}$} \\
\hline & & Measured & Calculated* & & & \\
\hline & $\mu \mathrm{g} / 100 \mathrm{ml}$ & \multicolumn{2}{|c|}{$\mu g / 100 \mathrm{ml}$} & $\%$ total $T_{4}$ & $n g / 100 m l \ddagger$ & \\
\hline \multicolumn{7}{|c|}{ Molar pregnancy $(9) \S$} \\
\hline 1 & 28.8 & 39.0 & 44.3 & 0.020 & 8.8 & 24.5 \\
\hline 2 & 16.4 & 24.0 & 25.2 & 0.024 & 5.9 & 19.7 \\
\hline 3 & 25.6 & 42.0 & 39.4 & 0.022 & 8.7 & 30.0 \\
\hline 4 & 16.4 & 21.0 & 25.2 & 0.029 & 7.1 & 21.0 \\
\hline 5 & 12.0 & 13.5 & 18.5 & 0.016 & 2.9 & 29.2 \\
\hline 6 & 17.6 & 25.0 & 27.1 & 0.023 & 6.2 & 19.6 \\
\hline 7 & 12.8 & 16.5 & 19.7 & 0.019 & 3.7 & 29.7 \\
\hline 8 & 24.8 & 45.0 & 38.2 & 0.032 & 12.3 & 27.5 \\
\hline 9 & 18.4 & 30.0 & 28.3 & 0.030 & 8.6 & 26.0 \\
\hline Mean $\pm \mathrm{SE}$ & $19.2 \pm 2.0^{\prime \prime}$ & $28.9 \pm 3.8$ & $29.5 \pm 3.0^{\prime \prime}$ & $0.024 \pm 0.002$ & $7.1 \pm 1.011$ & $25.2 \pm 1.4 \uparrow$ \\
\hline \multicolumn{7}{|c|}{ Normal pregnancy (8) } \\
\hline Mean $\pm \mathrm{SE}$ & $7.9 \pm 0.4$ & & $12.4 \pm 0.6$ & $0.021 \pm 0.001$ & $2.6 \pm 0.2$ & $34.2 \pm 1.2$ \\
\hline \multicolumn{7}{|c|}{ Nonpregnant controls (8) } \\
\hline Mean $\pm S E$ & $5.1 \pm 0.2$ & & $7.9 \pm 0.3$ & $0.028 \pm 0.001$ & $2.1 \pm 0.1$ & $18.1 \pm 1.0$ \\
\hline
\end{tabular}

* Calculated as PBI/0.65

$\ddagger$ Based on per cent total $T_{4}$ and calculated serum $T_{4}$ concentration.

$\S$ Numbers in parentheses indicate number of patients in group.

"Significantly different from both pregnant and nonpregnant groups $P<0.001$.

I Significantly different from pregnant group, $P<0.001$, and from nonpregnant group, $P<0.005$.

activity in bioassays of unconcentrated serum from 15 American and 3 Mexican women with normal pregnancy. In the assay, blood was obtained from test animals at 2 and $8 \mathrm{hr}$ after administration of the test serum. TSH potencies reported in Table VI are based upon the response at $2 \mathrm{hr}$ relative to the International Bovine Thyrotropin Standard because the slope of the thyroid

\section{TABLE V}

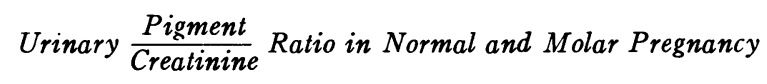

\begin{tabular}{lcl}
\hline \multicolumn{1}{c}{ Group } & $\begin{array}{c}\text { No. of } \\
\text { patients }\end{array}$ & $\frac{\text { Pigment }}{\text { Creatinine }} \times 100$ \\
\hline Nonpregnant & 12 & $153 \pm 11^{*}$ \\
Pregnant & & \\
$12-18 \mathrm{wk}$ & 10 & $219 \pm 10$ \\
$20-34 \mathrm{wk}$ & 10 & $263 \pm 22 \ddagger$ \\
$36 \mathrm{wk}$ & 17 & $330 \pm 17 \ddagger$ \\
Molar pregnancy & 9 & $571 \pm 140 \S$ \\
Postdelivery (1 wk) & 5 & $294 \pm 32$ \\
Postdelivery (4 wk) & 4 & $208 \pm 33$ \\
\hline
\end{tabular}

* Mean \pm SE.

† Significantly different from nonpregnant group.

$\S$ Significantly different from mid- and late-pregnant groups. stimulator in the serum of patients with hydatidiform mole was parallel to that of the bovine standard (21). The dose-response curve of the International Human $\mathrm{TSH}$ Standard is much flatter than that for bovine TSH in this bioassay (16) and would have given higher values than those reported had responses in these sera been related to the human standard curve. In specimens obtained before delivery from 6 patients in the initial group of 11 , thyrotropic activities were greatly elevated and ranged between 110 and $500 \mu \mathrm{U} / \mathrm{ml}$. In sera obtained as soon as 2 days after evacuation of the mole, no thyroid stimulator could be detected in the bioassay. The thyroid stimulator present in preevacuation sera differed from TSH in that a greater response was evident at $8 \mathrm{hr}$ than at $2 \mathrm{hr}$. The ratio of responses at 8 and $2 \mathrm{hr}$ ranged between 0.91 and 1.44, suggesting a longer duration of activity than that of pituitary $\mathrm{TSH}$, for which the $2 \mathrm{hr}$-response regularly exceeds the 8 -hr response (15). The thyroid stimulating activity in the predelivery serum of patient 27 was unaffected by prior incubation with antibody to human TSH (Table VII).

Radioimmunoassays for human TSH revealed values within the normal range in specimens obtained both before and after delivery of the mole (Table VI). Unlike the thyroid stimulating material that has been extracted from normal human placentas (15), the thy- 
TABLE VI

Bioassay and Immunoassay for Thyroid Stimulator in Serum Samples from Patients with Molar Pregnancy before and after Delivery

\begin{tabular}{|c|c|c|c|c|c|c|c|c|c|c|c|c|c|c|}
\hline \multirow[b]{2}{*}{ Patient No. } & \multicolumn{2}{|c|}{14} & \multicolumn{2}{|c|}{17} & \multicolumn{2}{|r|}{25} & \multicolumn{2}{|c|}{27} & \multicolumn{2}{|c|}{29} & \multicolumn{2}{|c|}{32} & \multicolumn{2}{|l|}{34} \\
\hline & Pre & Post & Pre & Post & Pre & Post & Pre & Post & Pre & Post & Pre & Post & Pre & Post \\
\hline \multicolumn{15}{|l|}{ Interval from day } \\
\hline of delivery (day) & -4 & 22 & -20 & 2 & - & -4 & -0.5 & 3 & -1 & 3 & -0.5 & 4.5 & -4 & 一 \\
\hline $\mathrm{r}, 2 \mathrm{hr} *$ & 3.90 & 1.25 & 1.40 & 0.95 & - & 1.17 & 3.58 & 1.12 & 3.75 & 1.01 & 2.55 & 0.99 & 3.79 & - \\
\hline $\pm S E$ & \pm 0.72 & \pm 0.12 & \pm 0.12 & & - & \pm 0.24 & \pm 0.45 & \pm 0.11 & \pm 0.72 & \pm 0.07 & \pm 0.40 & \pm 0.06 & \pm 1.03 & - \\
\hline $\mathrm{r}, 8 \mathrm{hr}$ & 5.61 & 1.14 & 1.86 & 1.35 & - & 1.16 & 4.32 & 1.43 & 4.45 & 1.12 & 3.26 & 1.09 & 3.50 & - \\
\hline 土SE & \pm 1.10 & \pm 0.04 & \pm 0.36 & & - & \pm 0.35 & \pm 0.36 & \pm 0.22 & \pm 0.88 & \pm 0.33 & \pm 0.54 & \pm 0.20 & \pm 0.37 & 一 \\
\hline $8 \mathrm{hr} / \mathrm{r} 2 \mathrm{hr}$ & 1.44 & 0.91 & 1.33 & 1.42 & 一 & 0.99 & 1.21 & 1.28 & 1.19 & 1.11 & 1.28 & 1.10 & 0.92 & - \\
\hline \multicolumn{15}{|l|}{$\begin{array}{c}\text { Thyroid stimulator } \\
\text { bioassay }\end{array}$} \\
\hline$(\mu U / m l)$ & $500 \ddagger$ & U\& & 110 & $\mathrm{U}$ & 一 & $\mathrm{U}$ & 4.30 & $\mathrm{U}$ & 460 & $\mathrm{U}$ & 260 & $\mathrm{U}$ & 470 & 一 \\
\hline \multicolumn{15}{|l|}{ Immunoassay $\mathrm{H}-\mathrm{TSH} \|$} \\
\hline$(\mu U / m l)$ & 11.6 & 7.2 & 8.8 & - & - & 9.3 & 9.3 & 8.1 & 11.5 & 8.0 & 5.6 & 6.7 & 5.8 & - \\
\hline
\end{tabular}

* Blood ${ }^{125} \mathrm{I}$ at $2 \mathrm{hr}$ or $8 \mathrm{hr}$ after injection of sample into mice, divided by blood ${ }^{125 \mathrm{I}}$ before injection. For controls injected with buffer, $\mathrm{r}$ was $1.09 \pm 0.07$ at $2 \mathrm{hr}$ and $1.31 \pm 0.10$ at $8 \mathrm{hr}$.

$\ddagger$ Based on the 2-hr response to the International Bovine Thyrotropin Standard.

\% Too low to be measured.

\| Normal range is $<1.8-12 \mu \mathrm{U} / \mathrm{ml}$.

roid stimulator present in the sera of patients with molar pregnancy did not cross-react in the radioimmunoassay for bovine TSH. Studies performed in the second group of nine sera revealed the presence of high titers of a thyroid stimulator similar in the temporal characteristics of its action to that found in the earlier group. Positive responses were obtained in sera from seven of nine patients. The two patients in whose sera the stimulator could not be detected were those in whom the PBI was the least increased. Very high titers of stimulator in patients 2,3 , and $8(2000,1200$, and 1300 $\mu \mathrm{U} / \mathrm{ml}$, respectively) permitted dilution of the sera for use in four point bioassays. These assays confirmed that the slope of this thyroid stimulator was parallel to that of the bovine standard.

\section{DISCUSSION}

Although previous reports have demonstrated the occurrence of thyroid hyperfunction in patients with molar pregnancy, the number of patients examined was few, and the tests performed were scattered. Hence, it was not possible to conclude whether the thyroid hyperfunction and the associated increase in serum PBI which had been described truly represented hypersecretion of thyroid hormone, particularly since clinical evidence of thyrotoxicosis was lacking. The present study comprises the largest number of observations in the largest number of patients with this disorder yet reported. While the study clarifies certain questions raised by earlier reports, others remain unanswered, and new questions have been raised.

The present observations in 11 patients studied before delivery of the mole have demonstrated consistent and marked thyroidal hyperfunction, as evidenced by greatly elevated values of the thyroidal ${ }^{181} \mathrm{I}$ uptake. That such hyperfunction was not the result of iodine deficiency was indicated by the finding of essentially normal, or occasionally increased, values for the daily urine iodine excretion, and ultimately by the demonstration that daily absolute iodine accumulation in the thyroid was increased, often greatly so. Values for thyroidal ${ }^{181} \mathrm{I}$ uptake were well into the range found in patients with thyrotoxicosis, and those for AIU were unusually high, even for patients with thyrotoxicosis $(18,19)$. More-

TABLE VII

Failure of Neutralization of the Bioassay Response to the Molar Thyroid Stimulator by Antibody to Human TSH

\begin{tabular}{lcc}
\hline & \multicolumn{2}{c}{ Response ratio $\pm \mathrm{SE}^{*}$} \\
\cline { 2 - 3 } Substance & $2 \mathrm{hr}$ & $8 \mathrm{hr}$ \\
\hline Control (buffer) & $1.10 \pm 0.08$ & $1.36 \pm 0.19$ \\
Human TSH standard $0.21 \mathrm{mU}$ & $2.75 \pm 0.45$ & $1.92 \pm 0.22$ \\
Human TSH standard $0.21 \mathrm{mU}$ & $1.01 \pm 0.07$ & $1.03 \pm 0.08$ \\
$\quad+$ anti H-TSH & & \\
Serum of patient $27,0.25 \mathrm{ml}$ & $2.48 \pm 0.31$ & $2.64 \pm 0.39$ \\
Serum of patient $27,0.25 \mathrm{ml}$ & $2.39 \pm 0.45$ & $2.69 \pm 0.56$ \\
$\quad+$ anti H-TSH $\ddagger$ & & \\
\hline
\end{tabular}

* Blood ${ }^{125} \mathrm{I}$ at $2 \mathrm{hr}$ or $8 \mathrm{hr}$ after injection of sample into mice, divided by blood ${ }^{125}$ I before injection.

† Sample was incubated with 0.1 volume $1 / 100$ antibody to human TSH for $18 \mathrm{hr}$ at $2^{\circ} \mathrm{C}$ before assay. Samples without antibody were diluted in same way. 
over, the consistent occurrence of abnormally high values for the $\mathrm{PB}^{131} \mathrm{I}$ concentration in serum provides evidence that the increased quantities of iodine accumulated by the thyroid were being rapidly secreted in an organically-bound form. Finally, analyses of serum by the highly specific technique of radioligand binding displacement indicated that most, if not virtually all, of the protein-bound iodine in the serum was comprised of $T_{4}$. Taken together, the foregoing findings provide strong evidence that in patients with molar pregnancy there occurs a pronounced increase in the secretion of T.

Several of the changes in certain aspects of thyroid hormone economy which occur in molar pregnancy resemble superficially those seen in normal pregnancy. These include the increase in thyroidal ${ }^{181} \mathrm{I}$ uptake and serum $\mathrm{PB}^{181} \mathrm{I}(22-25)$; in patients with molar pregnancy, however, these indices tended to be more markedly increased. Of greater importance is the fact that in normal pregnancy AIU is increased little if at all (25), and $T_{4}$ secretory rate, as judged from peripheral $\mathrm{T}_{4}$ disposal, is normal (26). In the present patients with molar pregnancy, AIU was consistently increased, often well into the range found in thyrotoxicosis, while evidence for hypersecretion of $T_{4}$ is present, as cited immediately above. Finally, values for serum PBI and $T_{4}$ concentration in molar pregnancy were usually much greater than in normal pregnancy.

The far higher values for serum PBI and $T_{4}$ in molar than in normal pregnancy cannot be explained by a greater increase in $\mathrm{T}_{4}$-binding by $\mathrm{TBG}$ in the former state. Indeed, on the average, values for the maximum binding capacity of TBG were lower than in normal pregnancy, although somewhat higher than in the nonpregnant female. Moreover, among patients with molar pregnancy, no correlation between values of the serum PBI and the $T_{4}$-binding capacity of TBG was evident. Values for the latter varied widely, some falling within the normal range and others within the range found in normal pregnancy. In these patients measurements of urinary estrogen excretion just before induction of labor, published in detail elsewhere (27), revealed no correlation between the binding capacity of TBG at that time and the excretion of either total estrogens or estrone and estradiol, which are far more potent than estriol in inducing an increase of TBG (28).

In view of the variability in the $T_{4}$-binding capacity of TBG and the evidence that the increased serum $\mathrm{T}_{4}$ concentration was at least partly the result of enhanced secretion of the hormone, and not solely secondary to an increase in TBG, it is not surprising that no clear correlations were evident among the $\mathrm{T}_{4}$-binding capacity of TBG, the $T_{4}$ concentration, and the proportion of free $T_{4}$ in the serum. Over the range which obtains in a variety of primary disorders of either thyroid function or hormonal binding, the proportion of free $\mathrm{T}_{4}$ in serum is inversely correlated with the concentration of unsaturated binding sites on TBG (29). Such correlations were difficult to seek in the present series of patients, because in the majority of instances the total serum $T_{4}$ concentration exceeded the maximum concentration of $\mathrm{T}_{4}$-binding sites on $\mathrm{TBG}$, often greatly. In such cases, it would be expected that the proportion of free $T_{4}$ would be substantially increased, and it seems anomalous that such was not the case; values in such cases being increased only moderately, if at all. Previous studies have suggested, however, that the extent of increase in the proportion of free $T_{4}$ that occurs when binding sites on TBG are saturated depends upon the availability of binding sites on TBPA $(9,30,31)$. Thus, for the group of patients with molar pregnancy as a whole, the relatively low values for the proportion of free $T_{4}$ in serum, despite very high values of the serum $T_{4}$ concentration, may have resulted from the modest increase in the $T_{4}$-binding capacity of TBG and the presence of nearly normal values for the binding capacity of TBPA.

With few exceptions $(15,32-34)$, previously reported cases of trophoblastic tumor which demonstrated thyroid hyperfunction or marked increases in serum PBI were peculiar in that they failed to display signs or symptoms of frank thyrotoxicosis. A similar paradox was evident in the present series of patients, who appeared clinically euthyroid and yet presented multiple lines of evidence suggesting hypersecretion of $T_{4}$. The presence of apparently normal concentrations of TSH in serum before evacuation of the mole does not, as might be expected, provide conclusive evidence against the presence of thyrotoxicosis in view of difficulty in distinguishing between normal and subnormal levels of $\mathrm{TSH}$, and the possibility that any $\mathrm{TSH}$ actually detected might represent a weak cross-reaction between high concentrations of the molar thyroid stimulator and human TSH $(21,32,34)$. Unfortunately, conventional indices of peripheral metabolic state, such as basal metabolic rate, could not be measured. Since random urine collections could be obtained, however, measurements of the urinary $\mathrm{P} / \mathrm{C}$ ratio could be made. The pronounced increase in this ratio which occurred in patients with molar pregnancy would suggest that the patients were indeed hypermetabolic, since the ratio has been shown to increase in association with hypermetabolism of either thyroidal or extrathyroidal origin (6-8). Nevertheless, so little is known of other factors which may influence this ratio that this cannot be considered conclusive evidence that the patients were hypermetabolic, let alone thyrotoxic.

The explanation for the absence of frank thyrotoxico- 
sis in most patients with molar pregnancy, despite evidence of pronounced hypersecretion of $T_{4}$, is unknown, but may relate to the magnitude of the increase in free $\mathrm{T}_{4}$ concentration in their serum. In patients with the usual varieties of hyperthyroidism, the absolute concentration of free $T_{4}$ in serum is usually quite elevated as a result of increases in both the total concentration of $T_{4}$ in serum and the proportion which is free. In most series, the absolute concentration of free $T_{4}$ in hyperthyroid patients averages about 5 times the normal value $(9,20,29,30)$; in the patients with molar pregnancy, a smaller increase in the concentration of free $T_{4}$ was generally seen, since the proportion of free $T_{4}$ was usually subnormal. Small to moderate increases in the serum concentration of free $\mathrm{T}_{4}$ in the absence of thyrotoxicosis are also seen in some patients with nonthyroidal illness $(9,20)$, as well as in patients receiving replacement doses of synthetic thyroxine (35). Hence, it may be, as earlier studies have also suggested (36), that patients can tolerate moderate increments in the availability of $T_{4}$ to tissues without developing frank thyrotoxicosis.

Although several questions concerning the changes in thyroid hormone economy which occur in molar pregnancy, such as the reasons for the variability in TBG or the absence of frank thyrotoxicosis, remain to be answered, it seems quite clear from the present data both that the intense thyroid hyperfunction seen in patients with molar pregnancy results from the highly active thyroid stimulator present in their serum and that the stimulator itself originates in the molar tissue. Consonant with this view is the rapid amelioration of thyroid hyperfunction and the often precipitous decrease in serum PBI associated with rapid disappearance of the stimulator from the serum after removal of the mole (Fig. 1). The nature of the unusual stimulator is uncertain. Bioassayable thyroid stimulating activity has been detected in serum or tumor from several patients with trophoblastic neoplasms $(21,32,37,38)$. Most germane to the present observations are the reports of Hershman and Higgins (32), who studied two patients with molar pregnancy, both of whom were thyrotoxic. Thyroid stimulating activity was found in both serum and extracts of tumor from one patient. Like the stimulator found in the present patients, it failed to demonstrate major immunologic cross-reaction with human TSH. Moreover, unlike normal chorionic thyrotropin, it failed to cross-react with bovine TSH. Gel filtration studies suggested that the thyroid stimulator in molar tissue has a higher molecular weight

"In the studies cited (35), the concentration of free triiodothyronine $\left(\mathrm{T}_{3}\right)$ was also moderately increased. No data concerning the proportion or concentration of free $T_{3}$ in the serum of patients with molar pregnancy are available.

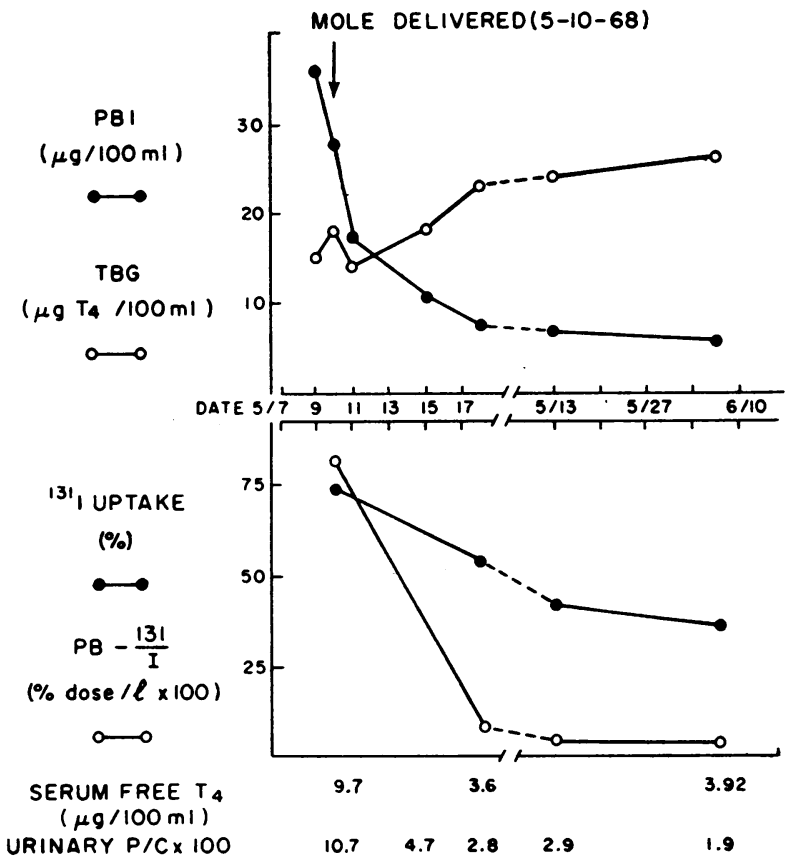

FIgURE 1 Thyroid function in a patient with molar pregnancy. Age 26, gravida 5, para 4, L. M. P. 2-12-67.

than bovine or human TSH or normal chorionic thyrotropin $(21,32)$. The material may be related to the thyrotropic substance found by Burger in commercial preparations of human chorionic gonadotropin obtained from the urine of normally pregnant women (39). This, too, appears to have a higher molecular weight than bovine TSH (39), and fails to crossreact immunologically with bovine or human TSH (21). Thus, it seems possible that the same thyroid stimulator that is secreted abundantly in patients with molar pregnancy may be secreted in small amounts by the normal human placenta.

\section{ACKNOWLEDGMENTS}

The authors gratefully acknowledge the generosity and assistance of the staff and patients of the Hospital de Gineco Obstetricia numero dos, Centro Medico Nacional, Mexico $7 \mathrm{DF}$, Mexico, where most of this study was carried out. This investigation was supported by Research Grants AM-05872, AM-09753, and AM-12366 from the National Institute of Arthritis and Metabolic Diseases, and by Grant FR-76 from the Division of Health Resources and Facilities, National Institutes of Health.

\section{REFERENCES}

1. Marquez-Monter, H., G. Alfaro de la Vega, and M. Robles. 1965. Hydatidiform mole. Ob./Gyn. Digest. $7: 69$.

2. Dowling, J. T., S. H. Ingbar, and N. Freinkel. 1960. Iodine metabolism in hydatidiform mole and choriocarcinoma. J. Clin. Endocrinol. Metab. 20: 1.

3. Kock, H., H. v. Kessel, L. Stolte, and H. v. Leusden. 1966. Thyroid function in molar pregnancy. J. Clin. Endocrinol. Metab. 26: 1128 . 
4. Dowling, J. T., N. Freinkel, and S. H. Ingbar. 1956. Thyroxine-binding by sera of pregnant women, newborn infants, and women with spontaneous abortion. J. Clin. Invest. 35: 1263.

5. Robbins, J., and J. H. Nelson. 1958. Thyroxine binding by serum protein in pregnancy and in the newborn. $J$. Clin. Invest. $37: 153$.

6. Drabkin, D. L. 1927. The normal pigment of the urine. II. The relationship of the basal metabolism to the output of normal urinary pigment. J. Biol. Chem. 75: 481.

7. Ostow, M., and S. Philo. 1944. The chief urinary pigment. The relationship between the rate of excretion of the yellow urinary pigment and the metabolic rate. Amer. J. Med. Sci. 207: 507.

8. Vorzimer, J. J., I. B. Cohen, and J. Joskow. 1949. The use of urinary pigment excretion for the measurement of basal metabolic rate. J. Lab. Clin. Med. 34: 482.

9. Ingbar, S. H., L. E. Braverman, N. A. Dawber, and G. Y. Lee. 1965. A new method for measuring the free thyroid hormone in human serum and an analysis of the factors that influence its concentration. J. Clin. Invest. 44: 1679 .

10. Murphy, B. E. P., and C. J. Pattee. 1964. Determination of thyroxine utilizing the property of protein binding. J. Clin. Endocrinol. Metab. 24: 187.

11. Benotti, J., and N. Benotti. 1963. Protein-bound iodine, total iodine, and butanol-extractable iodine by partial automation. Clin. Chem. 9: 408.

12. Braverman, L. E., A. E. Foster, and S. H. Ingbar. 1967. Sex-related differences in the binding in serum of thyroid hormones. J. Clin. Endocrinol. Metab. 27: 227.

13. Franklin, C., V. A. Galton, and S. H. Ingbar. 1970. Urinary pigment/creatinine ratio in normal and molar pregnancy. Obstet. Gynecol. In press.

14. Odell, W. D., P. L. Rayford, and G. T. Ross. 1967. Simplified, partially automated method for radioimmunoassay of human thyroid-stimulating, growth, luteinizing, and follicle stimulating hormones. J. Lab. Clin. Med. 70: 973.

15. Hershman, J. M., and W. R. Starnes. 1969. Extraction and characterization of a thyrotropic material from the human placenta. J. Clin. Invest. 48: 923.

16. Hershman, J. M. 1970. Different slopes of the doseresponse curves of human and bovine TSH in the McKenzie bioassay. Endocrinology. 86: 1004.

17. Snedecor, G. W., and W. G. Cochran. 1967. Statistical Methods. The Iowa State University Press, Ames, Iowa. 6th edition.

18. Burrows, B. A., and J. F. Ross. 1953. The thyroidal uptake of stable iodine compared with the serum concentration of protein-bound iodine in normal subjects and in patients with thyroid disease. J. Clin. Endocrinol. Metab. 13: 1358.

19. Reilly, W. A., K. G. Scott, G. L. Searle, and J. N. Castle. 1958. Iodide measurements in various functional states of the thyroid. Metab. (Clin. Exp.). 7: 699.

20. Oppenheimer, J. H., R. Squef, M. I. Surks, and H. Hauer. 1963. Binding of thyroxine by serum proteins evaluated by equilibrium dialysis and electrophoretic techniques. Alterations in nonthyroidal illness. J. Clin. Invest. 42 : 1769.

21. Hershman, J. M., H. P. Higgins, and W. R. Starnes. 1970. Differences between thyroid stimulator in a hydatidiform mole and human chorionic thyrotropin. Metab. (Clin. Exp.). 19: 735.
22. Pochin, E. E. 1952. The iodine uptake of the human thyroid throughout the menstrual cycle and in pregnancy. Clin. Sci. (London). 11: 441.

23. Ferraris, G. M., and A. Scorta. 1955. Comportamento di alcuni tests di funzione tiroidea in gravidanza $e$ in puerperio. Minerva Ginecol. 7: 308.

24. Halnan, K. E. 1958. The radioiodine uptake of the human thyroid in pregnancy. Clin. Sci. (London). 17: 281.

25. Aboul-Khair, S. A., J. Crooks, A. C. Turnbull, and F. E. Hytten. 1964. The physiologic changes in thyroid function during pregnancy. Clin. Sci. (London). 27: 195.

26. Dowling, J. T., W. G. Appleton, and J. T. Nicoloff. 1967. Thyroxine turnover during human pregnancy. $J$. Clin. Endocrinol. Metab. 27: 1749.

27. Brinck-Johnsen, T., J. Solc, and V. A. Galton. 1970. Urinary excretion of estrogens in women with hydatidiform mole and choriocarcinoma. Obstet. Gynecol. 36: 671.

28. Katz, F. H., and A. Kappas. 1967. The effects of estradiol and estriol on plasma levels of cortisol and thyroid hormone-binding globulins and on aldosterone and cortisol secretion rates in man. J. Clin. Invest. 46: 1768.

29. Hamada, S., T. Nakagawa, T. Mori, and K. Torizuka. 1970. Reevaluation of thyroxine binding and free thyroxine in human serum by paper electrophoresis and equilibrium dialysis, and a new free thyroxine index. J. Clin. Endocrinol. Metab. 31: 166.

30. Braverman, L. E., A. E. Foster, and S. H. Ingbar. 1968. Thyroid hormone transport in the serum of patients with thyrotoxic Graves' disease before and after treatment. J. Clin. Invest. $47: 1349$.

31. Woeber, K. A., and S. H. Ingbar. 1968. The contribution of thyroxine-binding prealbumin to the binding of thyroxine in human serum, as assessed by immunoadsorption. J. Clin. Invest. 47: 1710.

32. Hershman, J. M., and H. P. Higgins. 1971. Hydatidiform mole-A cause of clinical hyperthyroidism: Report of two patients with evidence that the molar tissue secreted a thyroidstimulator. $N$. Engl. J. Med. In press.

33. Mann, L. I., M. Lutz, H. Schulman, and S. L. Romney. 1967. Hydatidiform mole with hyperthyroidism. Amer. J. Obstet. Gynecol. 98 : 1151.

34. Cohen, J. D., and R. D. Utiger. 1970. Metastatic choriocarcinoma associated with hyperthyroidism. J. Clin. Endocrinol. Metab. 30: 423.

35. Braverman, L. E., A. Vagenakis, P. Downs, A. E. Foster, K. Sterling, and S. H. Ingbar. 1970. The effects of stable thyroxine $\left(T_{4}\right)$ replacement therapy on the peripheral metabolism of $T_{4}$ and triiodothyronine $\left(T_{3}\right)$. Proc. Int. Thyroid Conf., 6th. Vienna, Austria.

36. Danowski, T. S., M. E. Sarver, R. D. D'Ambrosia, and C. Moses. 1964. Hydrocortisone and/or desiccated thyroid in physiologic dosage. $\mathrm{X}$. Effects of thyroid hormone excesses on clinical status and thyroid indices. Metab. (Clin. Exp.). 13: 702 .

37. Odell, W. D., R. W. Bates, R. S. Rivlin, M. B. Lipsett, and R. Hertz. 1963. Increased thyroid function without clinical hyperthyroidism in patients with choriocarcinoma. J. Clin. Endocrinol. Metab. 23: 658.

38. Hennen, G. 1966. Detection of a thyroid stimulating factor in a choriocarcinoma occurring in a mole. Arch. Int. Physiol. Biochem. 74: 303.

39. Burger, A. 1967. Further studies on a thyroid stimulating factor in crude chorionic gonadotrophin preparations and in urine. Acta. Endocrinol. 55: 600. 